\title{
電磁波吸収シートによる導波管内の電磁波伝搬の隇衰効果
}

\author{
筒井和久 ${ }^{*}$, 遠藤博司 ${ }^{*}$, 齋藤章彦 ${ }^{*}$
}

\section{Attenuation of Electromagnetic Waves Propagating in Waveguides by Electromagnetic Wave Absorbing Sheets}

\author{
Kazuhisa Tsutsui, Hiroshi Endo, and Akihiko Saito
}

\section{Synopsis}

As the operating frequency becomes much higher, the electromagnetic interference turns to the critical issue in the metal cases of electronic devices. The electromagnetic wave absorber has been mounted on the cases in order to suppress the interference. Authors measured the attenuation of the electromagnetic wave in the waveguides simulating the metal case, lined with the synthetic rubber absorber, 0.5 to $3 \mathrm{~mm}$ in thickness, bearing Fe-7Cr-9Al soft-magnetic powder, 15 micrometer in diameter and 8 to $40 \%$ in volume. The reflection losses of the rubber absorbers were also measured and compared with the attenuation. In $10 \mathrm{GHz}$, the both losses reach maximum at the $25 \mathrm{vol} \%$ and $1.5 / 1.7 \mathrm{~mm}$ thick sheet. However, the attenuation and reflection losses show different characteristics in $22 \mathrm{GHz}$ and $28 \mathrm{GHz}$. In $22 \mathrm{GHz}$, although the reflection loss reach maximum at the $12 \mathrm{vol} . \%$ and $1.1 \mathrm{~mm}$ thick sheet, the maximum attenuation is at the 20 vol.\% and $1.1 \mathrm{~mm}$ thick sheet. In $28 \mathrm{GHz}$, although the reflection loss reach maximum at the 23 vol.\% and $0.7 \mathrm{~mm}$ thick sheet, but the maximum attenuation is at the $35 \mathrm{vol} . \%$ and $0.7 \mathrm{~mm}$ thick sheet. The results imply the design of the absorber should be based on the fine and delicate analysis of the suppression of the interference in the metal cases.

\section{1.緒言}

\section{1 電磁波吸収シートについて}

電磁波吸収体は，電波暗室の壁面やテレビのゴースト防 止用としてビルの壁面等に使用されてきた . いずれも遠方 からの平面波を対象としたもので, 電磁波吸収体の裏面に 金属板を配し，吸収体内部で多重反射を生じさせ，前面へ の総反射を低減させるものである . 最近では , カーボン粒 子やソフトフェライト (スピネル型) 粒子 ${ }^{1)}$, ハードフェ ライト (六方晶系) 粒子 2) , 金属軟磁性粉末 ${ }^{3-5)}$ 等をゴム や樹脂に混ぜてシート状にした電磁波吸収シートが開発さ れている．電磁波吸収シートは，いずれも薄型で，高い損 失を有し, 電磁波エネルギーを熱に変換 (吸収) できるこ とから，樣々な周波数用途での使用が検討されている.

これらの電磁波吸収シートは, 一般に自由空間法や導波 管法あるいは同軸管法による反射減衰量により評価され る.すなわち, 電磁波吸収シートの裏面に金属板を配し, 表
面より平面波を垂直に入射したときの反射が，金属板のみ の場合に比べて, どの程度減衰するかを測定する方法が採 れらている．本論文では，この減衰量を反射減衰量と呼ぶ．

\section{2 筐体内部干渉について}

近年, デジタル電子機器が急速な普及し, 不要電波が問 題となってきた .これらの不要電波は周辺機器に悪影響を 与える.従来の真空管やトランジスタなどを使った電子機 器と異なり,最近の電子機器は外部からの電波に敏感であ り，微弱な外来電波に対して誤作動を起こしたり，壊れた りするケースが報告されている ${ }^{6)}$. パソコン等の動作ク ロック周波数の高速化に伴い, マイクロ波帯での EMC も 問題になっている．弚の一方で電磁波利用の拡大が進み， 使用される周波数帯も以前に比べると格段に広い範囲に なりつつある .これまでは船舶・航空機無線やラジオ・テ レビ放送で MHz 帯の利用が主であったが, 携帯電話, 衛 星放送等, GHz 帯の利用が進んでいる。 
このような使用周波数の高周波化に伴い，筐体内部にお いても電磁干渉か問題となってきた .高周波化により，筐 体の大きさに比べて波長が十分に短くなると，内部の回路 や素子等から発生した電磁波が，筐体内部空間を伝搬す る.Fig.1に高周波増幅器での例を示す．高周波増幅器で は，筐体内部空間をラインから発生した電磁波が伝搬し， 入出力間の結合が発生する.この結合によりアンプの発振 やアンプゲインの不安定化を引き起こすとして問題と なっている．

この筐体内部の電磁波の伝搬対策として, 電磁波吸収 シートを筐体へ貼付し，筐体内部での電磁波の伝搬を減衰 させる手法が検討されている ${ }^{7,8,8,9)}$. しかしながら，筐体 内部の電磁波伝搬防止対策としての電磁波吸収シートの 有効性については確認されているものの, 詳細なメカニズ ムは明確でなく，また最適設計手法も確立されていない．

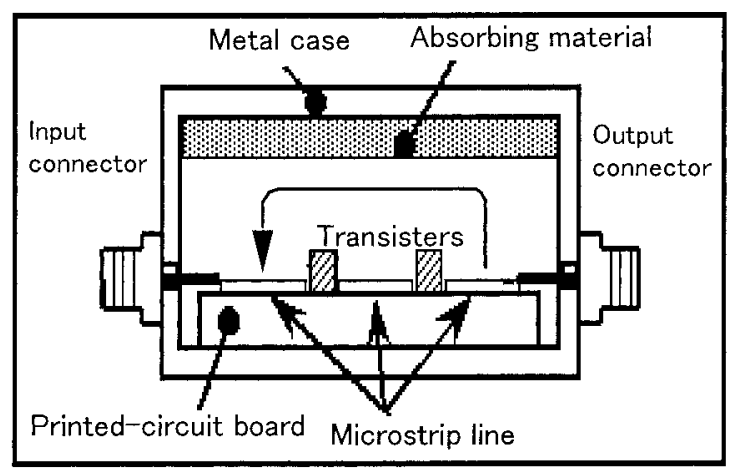

:Propagation of electromagnetic wave

Fig. 1. Counterplan for coupling in an amplifier module

\section{3 本研究の目的}

一般に電磁波吸収シートは,前述のように遠方界からの 平面波を対象とした反射減衰量を基に設計，評価される が, この手法で最適化された電磁波吸収シートが, 筐体内 部を伝搬する電磁波の抑制にどの程度有効であるかは，明 らかではない .

本論文では,反射減衰量を基に最適化された電磁波吸収 シートが,筐体内部の電磁波の伝搬抑制に対して，どの程 度有効であるかの手がかり得るために，導波管内での減 衰量と反射減衰量の比較を行った.多くの高周波増幅器の 筐体形状は直方体であり,入力端と出力端の電磁波の結合 を考えると，一般の方形導波管形状内のモ一ドの伝搬に類 似する . 方形導波管の伝搬モードは TE10 のみであり，筐 体内では高次モードも伝搬に寄与するが, 高次モードほど 減衰定数は大きく，モードの伝搬にはあまり寄与しないと 仮定し，产のドミナントモードである TE10に対して，電 磁波吸収シートの貼付による減衰効果を測定した．すなわ
ち,導波管を筐体と見立て，内部に電磁波吸収ゴムシート を置いた場合の電磁波の伝搬特性と, 平面波の垂直入射に 対する反射減衰量を測定し，両者を比較した．

\section{2 . 実 験}

\section{1 反射減衰量の計算}

電磁波吸収シートは,一般にはインピーダンス整合型電 磁波吸収体として設計される ${ }^{10)}$.すなわち Fig.2に示すよ うに電磁波吸収シートの裏面を金属板で裏打ちし, 吸収体 内部で多重反射を生じさせ,前面への総反射を低減させる ものである この電磁波吸収シートに電磁波が垂直に入射 した場合, 電磁波吸収シート前面のインピーダンス $Z_{i n}$ は, $\mathrm{Z}_{\text {in }}=\mathrm{Z}_{0}\left(\mu_{\mathrm{r}} / \epsilon_{\mathrm{r}}\right)^{1 / 2} \times \tanh \left[\{(\mathrm{j} \cdot 2 \pi f d) / c\}\left(\mu_{\mathrm{r}} \cdot \epsilon_{\mathrm{r}}\right)^{1 / 2}\right](1)$ で現される.ここで $\mu_{\mathrm{r}}, \epsilon_{\mathrm{r}}$ は乥れ尓れ電磁波吸収シート の複素透磁率, 複素誘電率, $d$ は吸収体の板厚, $c$ は光 速， $Z_{0}$ は大気中での特性インピーダンス， $f$ は入射する 電磁波の周波数である. 吸収体表面の反射係数「は

$$
\Gamma=\left(Z_{\text {in }}-1\right) /\left(Z_{\text {in }}+1\right)
$$

であるから，この時の反射減衰量 $(R L)$ は

$$
R L=20 \cdot \log \Gamma \quad(\mathrm{dB})
$$

となる.従って電磁波吸収シートの透磁率, 誘電率および 板厚が分かれば，反射減衰量は計算にて導出される．

本研究では, $10 \mathrm{GHz}, 22 \mathrm{GHz}, 28 \mathrm{GHz}$ の各周波数で最大 の反射減衰量を持つような透磁率, 誘電率, 板厚の組み合 わせを算出し，これを実現させる金属充填率を次の樣に予 測した .すなわち，10GHz に対して金属充填率 $25 \mathrm{vol}$ \% ， 板厚 $1.5 \mathrm{~mm} ， 22 \mathrm{GHz}$ に対して金属充填率 $12 \mathrm{vol} . \%$, 板厚 $1.1 \mathrm{~mm}, 28 \mathrm{GHz}$ に対して金属充填率 $23 \mathrm{vol}$ \% ，板厚 $0.7 \mathrm{~mm}$ とした .

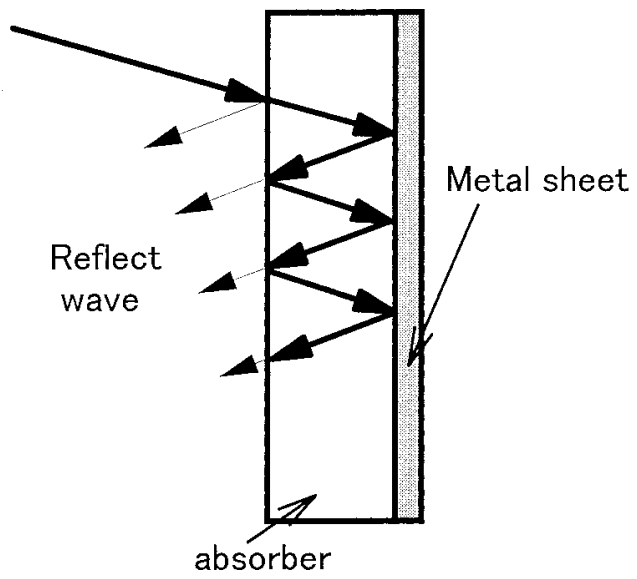

Fig. 2. Impedance matched type absorber. 


\section{2 電磁波吸収シートの作製}

実験には，軟磁性粉末をゴムに混練してシート化した電 磁波吸收シートを使用した .Fig.3に光の試作工程を示す． 軟磁性粉末にはアトマイズ法により作製した $\mathrm{Fe}-7 \mathrm{Cr}$ 9Al (平均粒径 $15 \mu \mathrm{m}$ ) を,ゴムは塩素化ポリエチレンを 使用した ·また,成形性を考慮して炭酸カルシウムを適宜 添加した .

アトマイズ法により作製した粉末をミキシングロール でゴムと混練し ,カレンダーロールにてシート化した .金 属充填率と板厚は，2.1 で予測した各周波数に対する值 とした .また各周波数での金属充填率の影響，あるいは板 厚の影響を調べるため 粉末の充填率は ,8vol.\%から 40vol. \%の範囲で変化させ , シート厚は, 数枚を重ねることによ り $0.5 \mathrm{~mm}$ から $3.0 \mathrm{~mm}$ の範囲で変化させた .

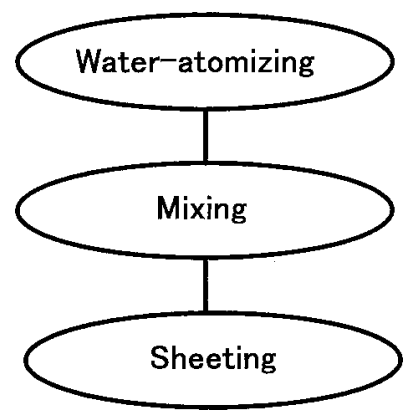

Fig. 3. Trial manufacturing process of the wave absorber sheet.

\section{3 測定方法}

\section{3 .1 反射減衰量測定}

反射減衰量は, $0 \sim 18 \mathrm{GHz}$ では同軸管法を用い, $18 \mathrm{GHz}$ 〜 40GHz 以上では導波管法を用いて測定した .Fig.4 に測 定系の概略図を示す.測定は同軸管または導波管にサンプ

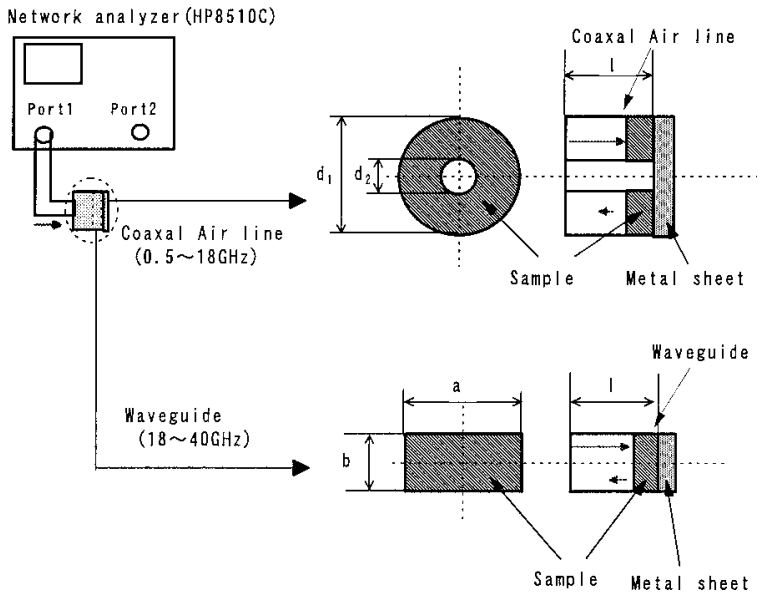

Fig. 4. Schematic diagram of measurement devices of reflection loss

ルを隙間なく挿入し，裏面を金属板で裏打ちした状態で， 表面側より平面波を垂直入射させ,ネットワークアナライ ザにより反射減衰量を測定した . Table. 1 に使用した同軸 管および導波管を示す。

\section{3 .2 導波管内減衰量測定}

筐体内部での電磁波の伝搬を擬似的に評価するため，

Fig.5 に示す測定系を用いた，導波管内に電磁波吸収シー 卜を配置しこの状態でネットワークアナライザ (HP8510C) を用いて透過減衰量を測定した。測定に使用 した導波管とサンプルサイズを Table 2 に示す. 以後，電 磁波吸収シートの長さ $(\mathrm{cm})$ 当たりの透過減衰量を導波 管内減衰量と呼ぶ . 本測定は, Fig.1 の樣な筐体内部の電 磁波の伝搬に対し，導波管を筐体に，またネットワークア ナライザの1ポートから入射される電磁波を筐体内部を伝 搬する電磁波に対応させモデル化したものであり，電磁波

Table 1. The size of coaxial air line and waveguides for measurement of reflection loss.

\begin{tabular}{ccccc}
\hline $\begin{array}{c}\text { Frequency } \\
\text { range }(\mathrm{GHz})\end{array}$ & Fixture & $\begin{array}{c}\text { Size } \\
(\mathrm{mm})\end{array}$ & $\begin{array}{c}\text { Length } \\
(\mathrm{mm})\end{array}$ & $\begin{array}{c}\text { Sample size } \\
(\mathrm{mm})\end{array}$ \\
\hline $0.5 \sim 18$ & Coaxial air line & $\varphi 7.00 \times \varphi 3.04$ & 5 & $\varphi 7.00 \times \varphi 3.04 \times \mathrm{t}$ \\
\hline $18 \sim 26.5$ & $\begin{array}{c}\text { waveguide } \\
\text { (WRJ-220) }\end{array}$ & $10.67 \times 4.32$ & 5 & $10.67 \times 4.32 \times \mathrm{t}$ \\
\hline $26.5 \sim 40$ & $\begin{array}{c}\text { waveguide } \\
\text { (WRJ-260) }\end{array}$ & $7.11 \times 3.56$ & 5 & $7.11 \times 3.56 \times \mathrm{t}$ \\
\hline
\end{tabular}

Table 2. The size of waveguides and samples for measurement of waveguide attenuation.

\begin{tabular}{ccccc}
\hline Form of waveguide & $\begin{array}{c}\text { Frequency range } \\
(\mathrm{GHz})\end{array}$ & $\begin{array}{c}\text { Width } \times \text { Height } \\
(\mathrm{mm})\end{array}$ & $\begin{array}{c}\text { Length } \\
(\mathrm{mm})\end{array}$ & $\begin{array}{c}\text { Sample size } \\
(\mathrm{mm})\end{array}$ \\
\hline WRJ-10 & $7 \sim 15$ & $22.9 \times 10.2$ & 270 & $22.8 \times 100 \times \mathrm{t}$ \\
\hline WRJ-220 & $18 \sim 26.5$ & $10.668 \times 4.318$ & 70 & $10.5 \times 70 \times \mathrm{t}$ \\
\hline WRJ-260 & $26.5 \sim 40$ & $7.112 \times 3.556$ & 50 & $7.0 \times 50 \times \mathrm{t}$ \\
\hline
\end{tabular}


吸収シートの挿入による電磁波の減衰効果を調べることを 目的とした 、測定は吸収シートが無い場合を基準とし，吸 収シートを配置した場合の透過減衰量（S21）を測定した。

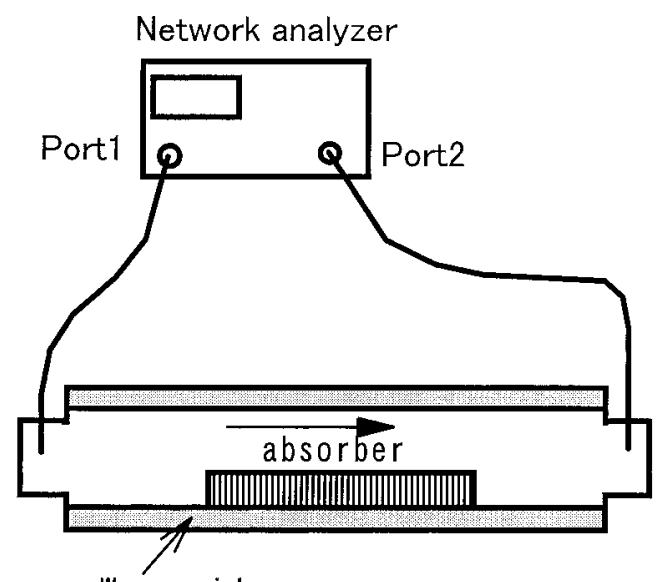

Waveguide

$\longrightarrow$ : electromagnetic wave from Port1

Fig. 5. Schematic diagram of measurement devices of waveguide attenuation.

\section{3.結果および考察}

\subsection{GHz 帯での減衰効果}

まず $10 \mathrm{GHz}$ 帯での反射減衰量と導波管内減衰量の比較 実験を行った . 実験の結果をFig.6 に示す . 10GH z で最 適な反射減衰量を持つ条件は，金属充填率 $25 \mathrm{vol}$ \% ，板厚 $1.5 \mathrm{~mm}$ と予測されたため，ここでは金属充填量を $25 \mathrm{vol} . \%$ とし, 板厚を $1.3 \sim 3.0 \mathrm{~mm}$ の間で変化させた . また板厚 $1.5 \mathrm{~mm}$ の電磁波吸収シートの $\mu_{\mathrm{r}}, \epsilon_{\mathrm{r}}$ を測定し，(1)〜

(3) 式により求めた計算値もプロットした .

金属充填率 $25 \mathrm{vol} . \%$ 板厚 $1.5 \mathrm{~mm}$ としたシートの反射減 衰量は，10GHz で最大の反射減衰量となり計算値と良い 一致を示す .反射減衰量は, 板厚が厚くなるに従いピーク が低周波側にシフトする .この場合金属充填率一定である から $, \mu \mathrm{r}, \epsilon \mathrm{r}$ はすべてのサンプルで一定であり，(1) 式 からも板厚増加によるピークの低周波化が予測され，測定 結果と一致する .

一方，導波管内に電磁波吸収シートを配置した場合の結 果を見ると，板厚の増大に従い, 最大吸收点が低周波側へ とシフトし，反射減衰量の場合とほぼ同樣の傾向を示す また反射減衰量に比べ,光のピークがブロード化している ことも確認される .

Fig.7 は 10GHzでの反射減衰量および導波管内減衰量の
値と，板厚との関係を示す. $10 \mathrm{GHz}$ 用電磁波吸収シート

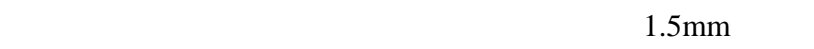
り，導波管内減衰量では $1.7 \mathrm{~mm}$ で最大の減衰となる，乥 の最適厚にわずかな差はあるものの，弚の傾向は両者で一 致している.

次に金属充填量に対する依存性を調査するため,金属充 填率を変化させ同樣の実験を行った．実験は板厚を $1.5 \mathrm{~mm}$ 一定とし，金属充填率を $20 \mathrm{vol} . \%$ から $40 \mathrm{vol}$ \% まで变化さ せた . 結果をFig.8 に示す . 反射減衰量は板厚を変化させ た場合と同樣に,金属充填率が多くなるに従い吸収ピーク が低周波側へとシフトする これは金属充填量を多くする と, シートの $\mu_{\mathrm{r}}, \epsilon_{\mathrm{r}}$ が共に増大するためで, 式 (1)に 従った変化である。一方, 導波管内減衰量は, 金属充填率 を多くするに従いピークは低周波側へとシフトし この場 合も Fig.6 同樣，反射減衰量と同じ傾向を示す.

Fig.9 は 10GHzでの反射減衰量および導波管内減衰量の
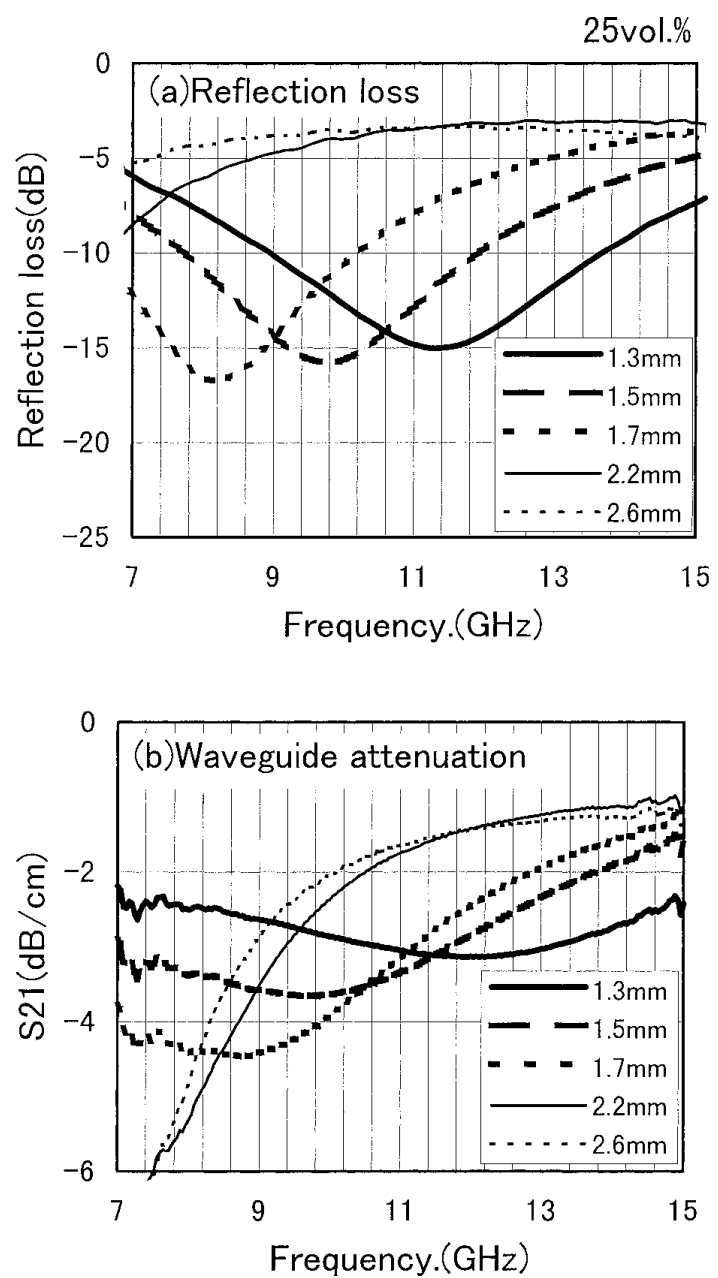

Fig. 6. Thickness dependence of (a)reflection loss and (b) waveguide attenuation in the renge of $7 \sim 15 \mathrm{GHz}$. 

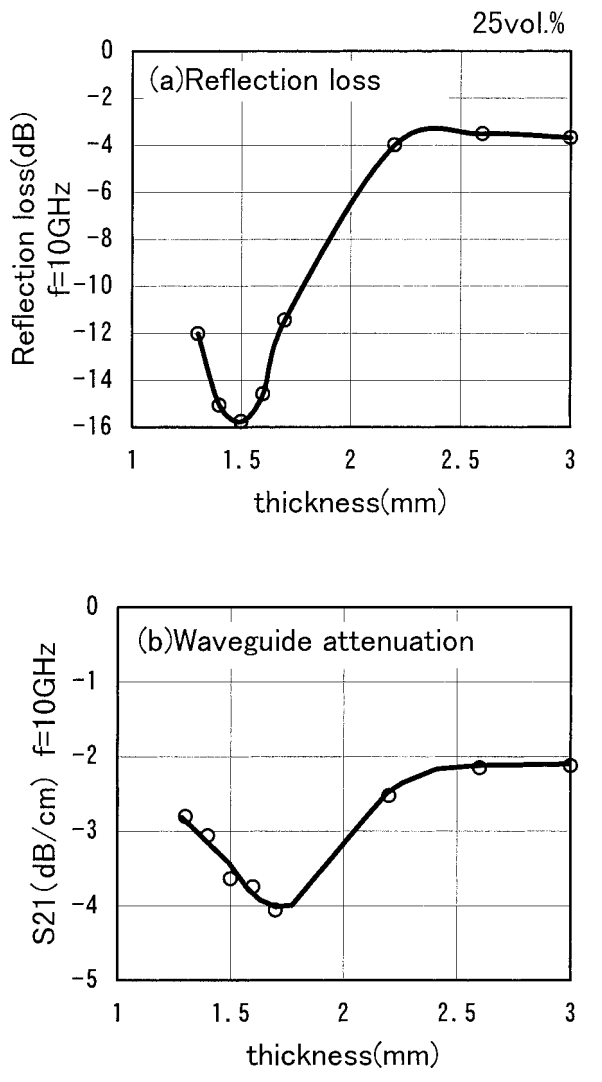

Fig. 7 Thickness dependence of (a) reflection loss and (b) waveguide attenuation at $10 \mathrm{GHz}$.
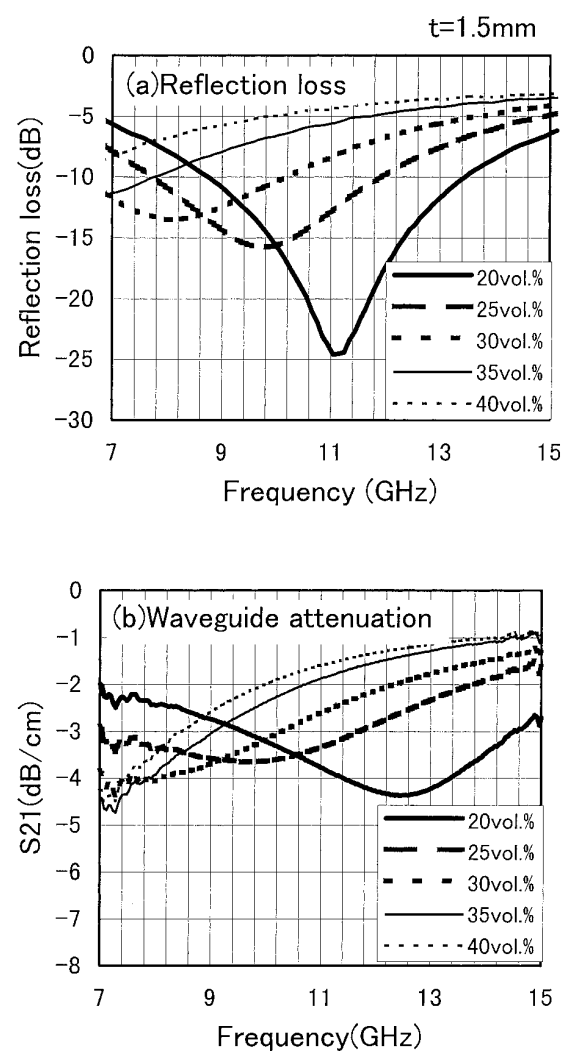

Fig. 8. Vol.\% dependence of (a) reflection loss and (b) waveguide attenuation in the range of $7 \sim 15 \mathrm{GHz}$.
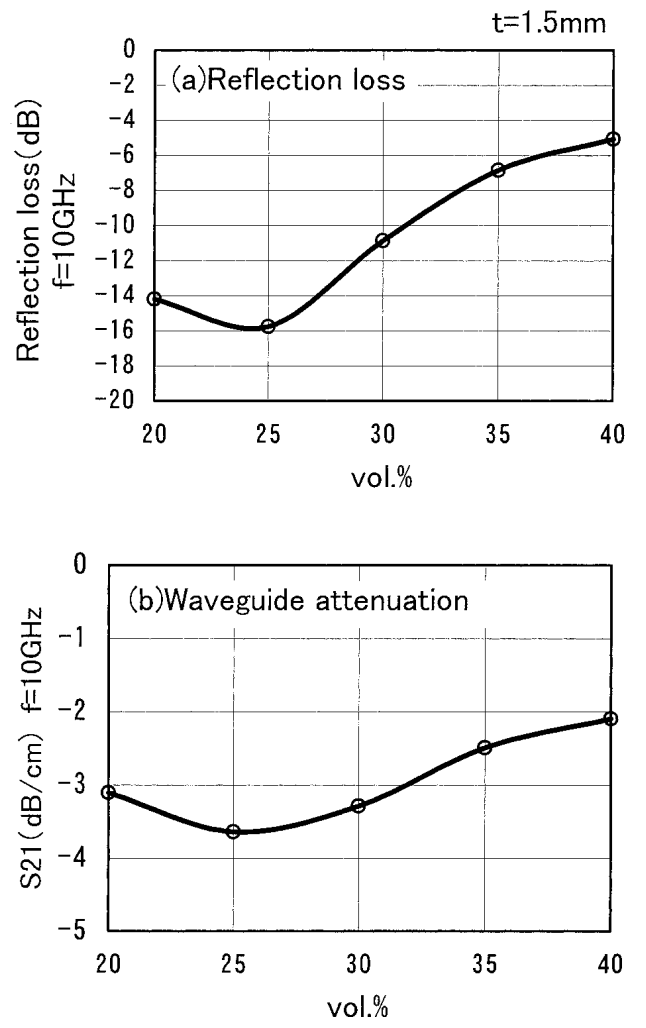

Fig. 9. Vol.\% dependence of (a) reflection loss and (b) waveguide attenuation at $10 \mathrm{GHz}$.

值と, 金属充填率との関係を示す. 反射減衰量, 導波管内 減衰量は $25 \mathrm{vol} . \% の$ 金属充填率で最大の減衰量を示し，ほ ぼ同樣の変化を示す .

以上のことから，10GHz 付近の周波数帯では, 反射減 衰量と導波管内減衰量の金属充填率依存性および板厚依 存性は良い一致を示すことが分かる．

\section{$3.222 \mathrm{GHz}, 28 \mathrm{GHz}$ での減衰効果}

$22 \mathrm{GHz}$ および $28 \mathrm{GHz}$ において同樣の実験を行った . $22 \mathrm{GHz}$ は加入者系無線アクセスシステム用として開放さ れている周波数であり, 高周波アンプにおける入出力間結 合が問題となっている周波数である.

予測による $22 \mathrm{GHz}, 28 \mathrm{GHz}$ で最大の反射減衰量が得られ る条件は，弚れ午れ金属充填率 $12 \mathrm{vol}$ \% ，板厚 $1.1 \mathrm{~mm}$ およ び金属充填率 $23 \mathrm{vol}$ \% ，板厚 $0.7 \mathrm{~mm}$ であった．なお，これ らの試作材の $\mu_{\mathrm{r}}, \epsilon_{\mathrm{r}}$ からの反射減衰量計算値と実測値と は，この周波数でも良く一致していることを確認した .

まず,金属充填率を $12 \mathrm{vol} . \%$ として，板厚を $0.9 \mathrm{~mm}$ から $2.6 \mathrm{~mm}$ まで变化させ, $22 \mathrm{GHz}$ における反射減衰量と導波 管内減衰量の比較実験を実施した . 結果をFig.10に示す. この周波数でも反射減衰量は板厚依存性を持っており, 計 
算による予測通り，最適板厚 $1.1 \mathrm{~mm}$ で最大の減衰量を示 し，板厚が光れよりずれると关の減衰量は大きく減少す る.これに対し導波管内減衰量の結果を見ると，板厚 $1.3 \mathrm{~mm}$ までは板厚の増大に伴い減衰量は急激に増大し，乥 の後も板厚の増大に伴い緩やかに増大する .この変化は反 射減衰量とは明らかに異なっている。

Fig.11に，28GHz において同樣の実験を行った場合の 結果を示す.ここでは金属充填量を $23 \mathrm{vol}$ \% \%で一定とし， 板厚を $0.5 \mathrm{~mm}$ から $1.8 \mathrm{~mm}$ まで変化させた . 結果はほぼ $22 \mathrm{GHz}$ の場合と同樣の傾向を示し，反射減衰量と導波管 内減衰量の金属充填率依存性は異なっている．

Fig.12 に，板厚を $1.1 \mathrm{~mm}$ 一定とし，金属充填率を $8 \mathrm{vol}$. \%から $30 \mathrm{vol} . \%$ まて変化させた場合の $22 \mathrm{GHz}$ における反 射減衰量と導波管内減衰量を示す.反射減衰量で考えた場 合，最適金属充填率は $12 \mathrm{vol}$ \% となるが，導波管内減衰量 で考えた場合の最適金属充填率は20vol.\%であり，両者の 最適点は異なっている.

Fig.13に，28GHzでの金属充填量に対する反射減衰量 と導波管内減衰量を示す.板厚は $0.7 \mathrm{~mm}$ 一定とし, 金属 充填率を $17 \mathrm{vol}$ \% \%から $40 \mathrm{vol}$ \% まで变化させた，反射減衰 量では $23 \mathrm{vol} . \%$ で最大の減衰量を示すのに対し, 導波管減 衰量では $35 \mathrm{vol}$ \% で最大の減衰量となり，ここでも両者の 最適金属充填率は異なっている．

これらより，22GHz，28GHzでは，反射減衰量と導波管 減衰量の变化は,板厚依存性, 金属充填率依存性の両方で 明らかに異なっている。

以上のように,電磁波吸収シートの設計パラメータであ る板厚と金属充填率を変化させて,反射減衰量と導波管内 減衰量の比較実験を行ったが, 周波数により両者の金属充 填率依存性，板厚依存性が異なっている場合があることが 本実験より明らかとなった ·高周波アンプ等, 筐体内部干 渉力㵍題となっている実際の機器においては, 产の形状も 樣々であり，また電磁波が伝搬する筐体内部の隙間も機器 によって異なるため，本研究での導波管内減衰量の結果 が,実際の機器内での効果兴のものを表したものとは言え ない.しかしながら，単純化した導波管での実験において も,反射減衰量と導波管内減衰量の相関か認められないこ とから,さらに複雑な構造でかつ高次モードの伝搬も予測 される実用筐体では，相関が無いことか推測される．

反射減衰量と導波管内減衰量の効果が一致しない要因， および周波数帯によって反射減衰量と導波管内減衰量の 関係が異なっている要因は,本研究からは明らかにできな かったが, 電磁波のシートへの入射形態の違い, 伝搬する
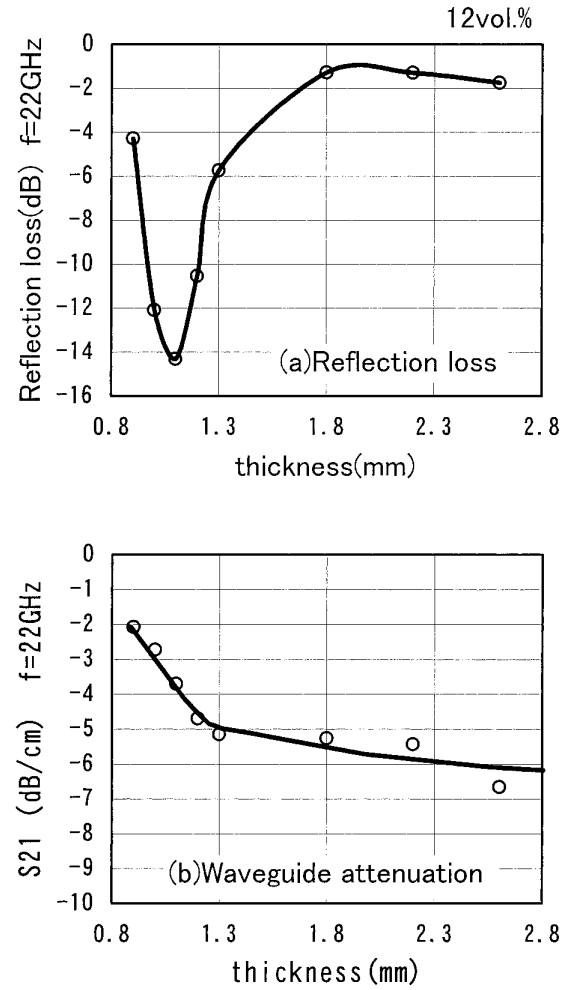

Fig. 10. Thickness dependence of (a) reflection loss and (b) waveguide attenuation at $22 \mathrm{GHz}$.
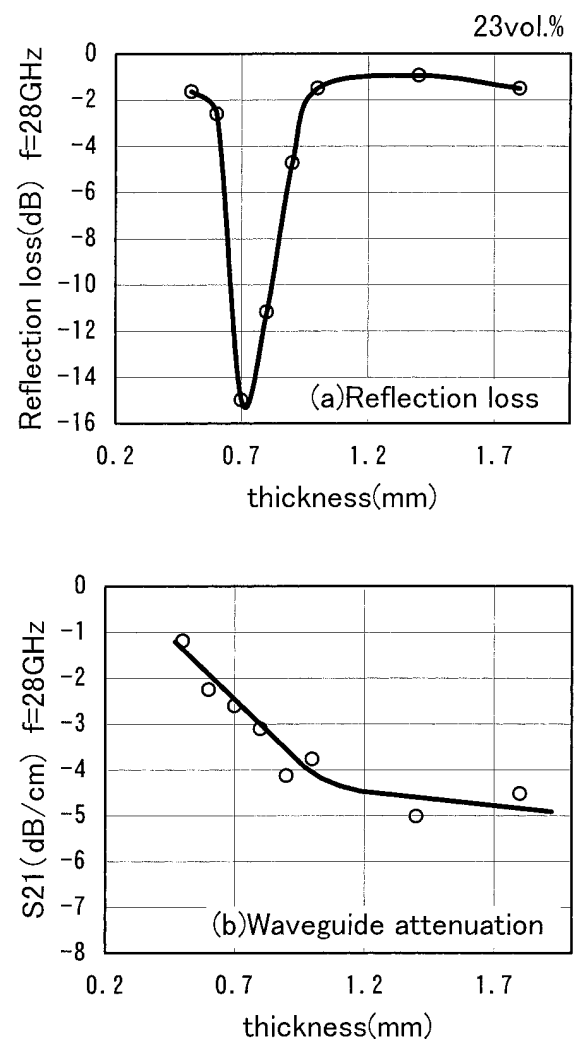

Fig. 11. Thickness dependence of (a) reflection loss and (b) waveguide attenuation at $28 \mathrm{GHz}$. 

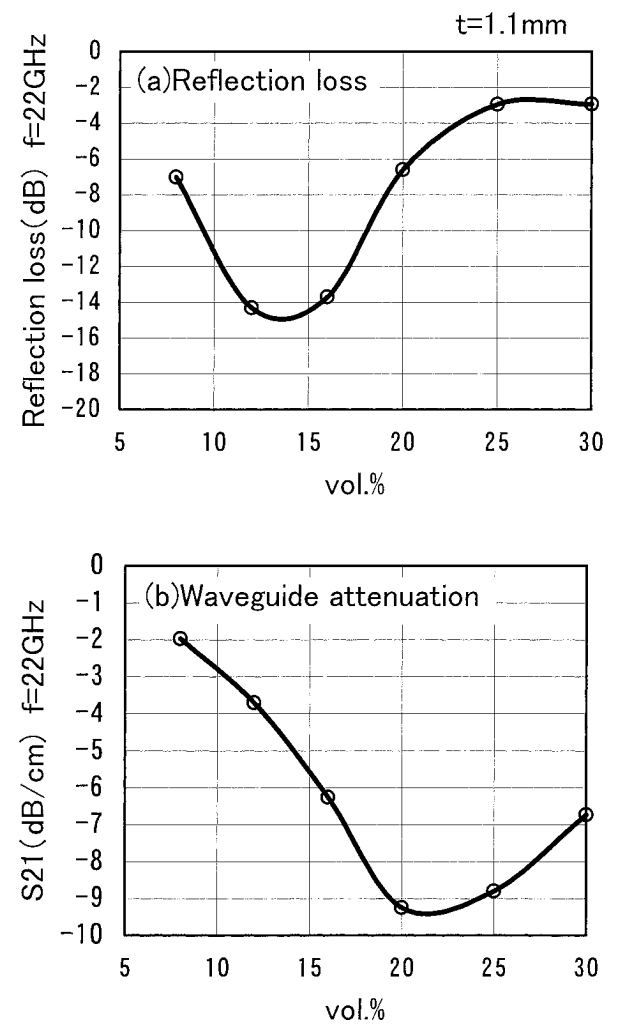

Fig. 12. Vol.\% dependence of (a) reflection loss and (b) waveguide attenuation at $22 \mathrm{GHz}$.
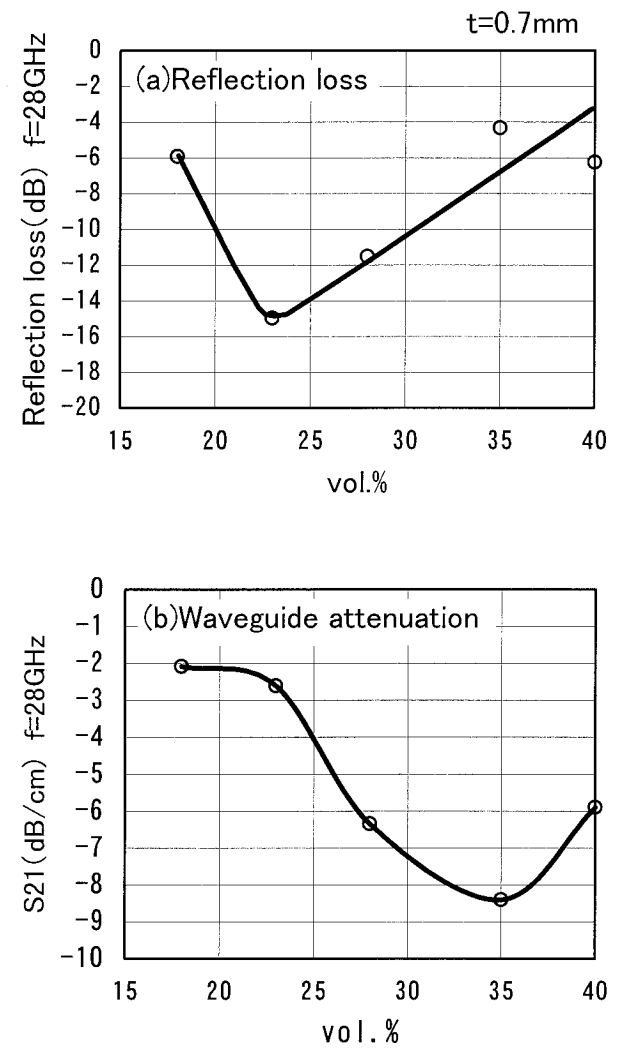

Fig. 13. Vol.\% dependence of (a) reflection loss and (b) waveguide attenuation at $28 \mathrm{GHz}$.
空間の違い等が考えられる.今後電磁波吸収シートによる 筐体内部干渉抑制メカニズムを明らかにし，光の設計手法 を明らかにすることは，実用上，重要な課題といえる．

\section{4 .まとめ}

本研究では, 導波管の内部に電磁波吸収シートを置いた 場合の電磁波の伝搬特性を調べた。乥の結果，反射減衰量 と導波管内減衰量が最大となる金属充填率あるいは板厚 は，必ずしも一致しないことが分かった .

(1) $10 \mathrm{GHz}$ 帯では，反射減衰量，導波管内減衰量共に，金 属充填率 $25 \mathrm{vol}$ \% , 板厚 $1.5 \sim 1.7 \mathrm{~mm}$ て最も高い減衰量を 示す．

(2) $22 \mathrm{GHz}$ では，反射減衰量は，金属充填率 $12 \mathrm{vol} \% \%$ ，板厚 $1.1 \mathrm{~mm}$ で最も高い減衰量を示すのに対して 導波管内減衰 量は金属充填率 20vol. \% 板厚 $1.1 \mathrm{~mm}$ で最大の減衰量とな る。

(3) $28 \mathrm{GHz}$ では, 反射減衰量は, 金属充填率 $23 \mathrm{vol}$ \% , 板厚 $0.7 \mathrm{~mm}$ で最も高い減衰量を示すのに対して 導波管内減衰 量は金属充填率 $35 \mathrm{vol} . \%$, 板厚 $0.7 \mathrm{~mm}$ で最大の減衰量とな る。

従って，筐体内の電磁波の伝搬抑制効果と反射減衰量の 間には相関が無いことが推測される.今後新たな電磁波吸 収体の設計技術を確立することか課題である。

\section{謝 辞}

本研究を遂行するに当たり，一連の実験の実施に協力し ていただいた大同特殊鋼㛦技術開発研究所 電磁材料研究 部 磁性材料研究チームの小出茂氏, 田中伸明氏に感謝し ます．

\section{(文 献)}

1)内藤, 藤原: 電子情報通信学会論文誌 $B, 53 B(1970), 537$.

2)杉本，本間:金属，69(1999),722.

3)吉田:日本応用磁気学会誌, 22(1998), 1353.

4)松本, 宮田:日本応用磁気学会誌,22(1998),885.

5)齋藤 小小，矢萩:電気製鋼，69(1998）, 195.

6)不要電波問題対策協議会カタログ

7)遠藤,筒井:工業材料, 48(2000)No.12.

8)齋藤, 西方: 電気情報通信学会総合大会,B-4-59(2000-3).

9)齋藤,西方:電気製鋼, 71(2000),279.

10)橋本“：電波吸収体入門”，森北出版，(1998) 